\title{
ETIKA MENULIS DENGAN CAHAYA
}

\author{
Agus Toto Widyatmoko \\ Mahasiswa Magister Ilmu Komunikasi Undip \\ Angkatan VII
}

\begin{abstract}
The mass media had great influence in conveying a message against their common. The values of the message was set out in the text and images are presented by the media. The message may contain meaning positive and inspiring in describing events, so that is not interfere psychological of audience. In the context of photojournalism, the expression that the power of the image can be far beyond the message conveyed through text. Because the meaning of the message, the essence of photojournalism must pay attention to the rules of journalism were set in the Press Law and the Code of Ethics of Journalism. An understanding of the ethics of photojournalism is not only for internal media, but also to a audience. Thus, the public can judge the mindset of media displaying photographic work does pay attention to aesthetic aspects or ignore the rules of journalism.
\end{abstract}

Keywords: Photojournalism, Press Law, the Code of Ethics Journalism, the Power of Image

\section{PENDAHULUAN}

Satu gambar bermakna seribu kata. Ungkapan populer ilustrator dan karikaturis Fred Barnard (1846-1896) itu menegaskan satu gambar lebih mendeskripsikan sebuah kejadian dibandingkan dengan kalimatkalimat panjang. Tampilan visual bisa diartikan, diterjemahkan, dan diulas dengan ribuan kata-kata. Gambar atau foto seringkali lebih lugas dalam menyampaikan informasi, tanpa harus diinterpretasikan dan ditafsirkan ulang oleh para penulis. Seringkali pula gambar, foto, ilustrasi secara cepat mampu memberikan informasi lebih detail tanpa perlu aktivitas lain. Cukup memandang foto, orang akan bisa menangkap dan menerima informasi dari tampilan tersebut secara baik.

Demikian halnya dengan kegiatan foto jurnalistik. Jurnalistik merupakan segala bentuk yang terkait dengan pembuatan berita dan dan ulasan mengenai berita yang disampaikan kepada publik. Proses jurnalistik itu melalui pengumpulan, penafsiran, penyebaran informasi umum, pendapat pemerhati, hiburan umum yang dikemas secara sistematis dan dapat dipercaya untuk diterbitkan pada surat kabar, majalah, dan disiarkan. Sedangkan foto jurnalistik adalah "menulis" dengan cahaya untuk mereportase kegiatan tersebut (Julianne dalam Bersak, 2006:7). Dalam praktiknya jurnalistik berkonotasi jauh dari definisi sederhana itu. Pewarta foto dalam proses pencarian foto jurnalistik tidak sekadar mengambil gambar. Seringkali pengambilan gambar harus menunggu momen terbaik dan membutuhkan waktu yang tidak singkat. Pewarta foto memerlukan kejelian dan kepekaan dalam mengambil sudut pandang sehingga informasi yang tersampaikan kepada publik tidak mengalami bias informasi.

Foto peresmian pabrik otomotif, misalnya, pewarta foto tidak sekadar mencari moment pengguntingan pita oleh seorang 
direktur. Foto jurnalistik tentu berbeda dengan foto dokumentasi. Pengambilan sudut pandang yang tepat akan memberikan informasi lebih dari sekadar peresmian pabrik. Proses pembuatan mobil di pabrik yang dilengkapi kecanggihan teknologi robotik akan memberikan makna 'lebih".

Foto jurnalistik merupakan praktik profesional. Wartawan foto mencari, membuat dokumen, dan menyajikan untuk audiens. Profesional karena produk mereka (1) disebarluaskan sebagai rekaman atas fakta visual; (2) audiens cenderung percaya akan apa yang kita lihat dan terlihat nyata. Oleh karena itu, makna dari foto jurnalistik membawa beban melampaui kata-kata.

Inti foto jurnalistik adalah koneksi intuitif dan orang lain. Hal ini dibuktikan dengan "panggilan" dari pewarta foto jurnalistik. Mereka ditegaskan sebagai perekam kejadian di berbagai tempat ke dalam kehidupan pribadi yang soliter. Mereka menempuh risiko tinggi untuk mendapatkan gambar/foto. Jurnalis foto yang baik adalah mencari tahu sendiri kebenaran peristiwa dengan mengumpulkan informasi visual. Menurut Henri Cartier-Bresson (1952) yang mengemukakan bahwa fotografi jurnalistik ke dalam sebuah foto yang berkisah, di mana dalam pelaporannya menggunakan sebuah kamera dalam waktu yang singkat dan foto tersebut mengungkap sebuah cerita

Dalam praktiknya tampilan yang disuguhkan di media seringkali menimbulkan perdebatan di tengah masyarakat. Media massa dalam menayangkan foto-foto kejadian kriminal, terorisme, bencana alam, dan kekerasan dianggap menonjolkan unsur-unsur kesadisan. Sementara dalam UU No 40 Tahun 1999 tentang Pers dan Kode Etik Jurnalistik Pasal 4 menegaskan bahwa wartawan Indonesia tidak membuat berita bohong, fitnah, sadis, dan cabul. Penafsirannya adalah sebagai berikut :

a. Bohong berarti sesuatu yang sudah diketahui sebelumnya oleh wartawan sebagai hal yang tidak sesuai dengan fakta yang terjadi.

b. Fitnah berarti tuduhan tanpa dasar yang dilakukan secara sengaja dengan niat buruk.

c. Sadis berarti kejam dan tidak mengenal belas kasihan.

d. Cabul berarti penggambaran tingkah laku secara erotis dengan foto, gambar, suara, grafis atau tulisan yang semata-mata untuk membangkitkan nafsu birahi.

e. Dalam penyiaran gambar dan suara dari arsip, wartawan mencantumkan waktu pengambilan gambar dan suara.

Dari aturan inilah muncul dilema etis yang seringkali diperdebatkan. Di satu sisi foto jurnalistik harus dapat memberikan pemberitaan visual sebagai tanggung jawab sosial dan berfungsi menyuarakan kebenaran visual yang memiliki integritas dan dapat dipercaya. Di sisi lain, foto jurnalistik dituntut untuk dapat memberikan sudut pandang visual yang menarik.

\section{PEMBAHASAN}

\section{Foto Jurnalistik}

Fotografi adalah perpaduan antara teknologi dan seni. Berbagai nilai keindahan atau estetika yang tidak tercakup dalam teknologi fotografi karena diselaraskan dengan proses teknis untuk memberikan karakter dan keindahan pada hasil visualnya. Untuk memahami fotografi, terdapat metode EDFAT yang dikemukakan oleh Walter Cronkite School of Jurnalism and Telecomunication, Arizone State University. EDFAT merupakan metode pengambilan gambar lewat kamera untuk melatih optis melihat sesuatu secara 
detail dan tajam. Metode EDFAT diterapkan untuk membantu proses pengambilan keputusan terhadap suatu kejadian atau kondisi visual yang memiliki cerita dan nilai berita secara cepat dan lugas. Proses yang dikerjakan pada setiap unsur dari metode tersebut merupakan tahapan dalam upaya memotret suatu bentuk visual dari peristiwa yang memiliki nilai berita dan layak disampaikan kepada publik. Unsur yang dimaksud dalam metode EDFAT tersebut seperti di bawah ini:

\section{- E berarti : Entire ( Keseluruhan )}

Tahapan ini dikenal juga sebagai established shot, yakni suatu keseluruhan pemotretan yang dilakukan setelah melihat suatu peristiwa atau bentuk penugasan lain untuk mengincar atau mengintai bagian-bagian yang dipilih sebagai obyek.

\section{- D berarti : Detail (Rinci)}

Proses ini diartikan sebagai suatu pilihan atas bagian tertentu dari keseluruhan pandangan terdahulu. Tahap ini adalah suatu pilihan pengambilan keputusan atas sesuatu yang dinilai paling tepat sebagai point of interest atau nilai-nilai ketertarikan. Setelah memahami obyek foto secara detail, fotografer bisa memasuki tahapan berikutnya.

\section{- F berarti : Frame ( Komposisi )}

Inilah tahapan di mana seseorang mulai membingkai detail obyek yang telah ditentukan. Tahap ini penting bagi calon foto jurnalis memahami makna sebuah komposisi, pola, tekstur, dan bentuk subyek pemotretan secara akurat. Sentuhan nilai artistik semakin penting dalam tahap ini. Seperti: foto dalam bentuk horizontal dan vertikal.

\section{- A berarti : Angle (Sudut Pandang)}

Proses ini menempatkan sudut pandang menjadi dominan, tinggi, rendah, level mata, kiri, kanan, dan cara melihat obyek. Dari proses ini foto jurnalistik mengonsepsikan visual seperti apa yang diinginkan. Seperti eye angle, low angle, dan high angle.

\section{- $\quad$ T Berarti : Time (Waktu)}

Tahap ini sangat menentuka ketepatan mengenai penyinaran dengan komposisi yang tepat antara besaran diafragma dan kecepatan atas ke empat tingkat yang telah disebutkan sebelumnya. Pengetahuan dan pemahaman teknis atas keinginan dalam memutuskan gerakan atau memilih ketajaman ruang adalah satu prasyarat dasar yang sangat diperlukan.

Melalui metode EDFAT yang tepat, seorang jurnalis foto memiliki insting memotret yang menurutnya memiliki cerita atau menjadi sebuah esai. Untuk membuat foto yanng bisa "berbicara" diperlukan kemampuan seorang fotografer, yaitu kombinasi dari naluri fotografer dan pengetahuan teknis mengenai fotografi. Oscar Motuloh dalam makalah berjudul ''Foto Jurnalistik, Suatu Pendekatan Visual dengan Suara Hati" (Wibowo, 2004: 15) menyebutkan foto jurnalistik merupakan sebuah medium sajian untuk menyampaikan beragam bentuk visual dari berbagai peristiwa. Bukan hanya dari lapisan terluar, melainkan sampai kerak di balik peristiwa tersebut. Keputusan pengambilan foto tersebut dikerjakan dalam tempo paling singkat.

Foto jurnalistik, menurut Thomas Elliot Berry, memiliki sejumlah fungsi. Pertama, untuk mengomunikasikan berita (to communicate the news), foto memiliki nilai 
yang sangat penting dalam penyampaian berita, bukan sekadar pelengkap atau aksesoris dari pesan yang ingin disampaikan komunikator. Ia menyempurnakan sajian suatu berita. Tanpa kehadiran foto, berita tersebut akan terasa hambar, tidak berbunyi. Kedua, foto jurnalistik menimbulkan minat (to generate interest). Ketiga, foto jurnalistik berfungsi untuk menonjolkan dimensi lain dari sebuah objek pemotretan yang dipublikasikan (to give another dimension to a newsworthy figure). Keempat, foto jurnalistik berfungsi untuk menambah nilai berita (sisi kualitas pemberitaan) tanpa mengurangi arti berita. Kelima, foto jurnalistik dimanfaatkan untuk keperluan tata rias/perwajahan surat kabar dan majalah secara garis besar yang bisa memberikan dampak pada seluruh perwajahan.

\section{Teori Normatif Media}

Teori normatif media massa menggagas pokok media seharusnya atau diharapkan, dikelola, dan bertindak untuk kepentingan publik dan kebaikan masyarakat. Situasi ini berangkat dari kenyataan bahwa media diasumsikan tidak hanya memiliki dampak obyektif, tetapi juga menjalankan tujuantujuan sosial tertentu. Misalnya media bisa digunakan untuk menghasilkan dampak yang direncanakan yang dianggap positif. Teori normatif media mengajukan empat model (McQuail, 2011: 204).

Pertama, model pluralis liberal atau pasar (liberal pluralist or market model). Model ini berdasarkan terori pers bebas yang memiliki kebebasan untuk mengoperasikan alat publikasi tanpa izin atau campur tangan negara. Ranah publik dilayani oleg pengoperasian pasar bebas ide. Akuntabilitas ublik diraih dengan cara pasar media dan pengaturan diri yang minimal dengan peranan minil untuk negara. Kedua, model tanggung jawab sosial (social responsibility or public interest model). Hak kebebasan penyiara dibarengi dengan kewajiban terhadap masyarakat luas melebihi kepentingan pribadi. media memeliharan standar tinggi, tetapi campur tangan pemerintah juga dilibatkan. Ketiga, model profesional (professional model). Masyarakat sebagai pengawal standard nilai dan profesi jurnalisme. Otonomi lembaga dan profesionalis dari jurnalisme menjadi jaminan terbaik sebagai bentuk pengawasan terhadap pemegang otoritas. Keempat, model media alternatif (alternatifve media model). Model ini mewakil media nonmainstream yang memiliki tujuan berbeda.namun terdapat nilai bersama, terutama pada arus bawah atau masyarakat umum serta oposisi terhadap kekuasaan (McQuail, 2011: 204).

Dalam hal ini, teori normatif media memandang bahwa media massa dianggap sebagai media yang melayani tujuan sosial, termasuk dalam menyajikan foto jurnalistik juga memperhatikan tanggung jawab sosial yang dimilikinya. Teori normatif mengacu pada ide-ide tentang bagaimana struktur konten media seharusnya dan berperilaku untuk kepentingan umum yang lebih luas atau untuk kebaikan masyarakat secara keseluruhan.

Media melaksanakan sejumlah tugas penting dan esensial dalam menginformasikan sesuatu kepada masyarakat dan selalu berpegang pada kepentingan publik. Oleh karena itu, di dalam teori normatif media terdapat model tanggungjawab sosial. Teori ini fokus pada sistem yang dioperasikan oleh media haruslah sesuai dengan prinsip dasar yang sama, yang mengatur ke seluruh elemen masyarakat, terutama dalam kaitannya dengan keadilan, keterbukaan, demokrasi dan pengertian akan nilai-nilai sosial dan budaya yang diinginkan. Paling tidak, apa yang 
diinformasikan oleh media tidak menimbulkan persoalan sosial atau pelanggaran yang ekstrem. Terdapat pula mekanisme akuntabilitas terhadap khalayak.

Foto jurnalistik yang baik memenuhi memenuhi aturan kepentingan publik tersebut. Kebebasan mengekspresikan visualisasi gambar dalam foto jurnalistik bersifat terbatas dengan alasan tanggungjawab sosial. Ketika foto jurnalistik itu diatur sedemikian rupa, maka sesuai dengan pernyataan Bates (2001) dalam Baran (2012: 115), yaitu pers tidak bebas jika mereka yang mengoperasikannya bersikap seolah-olah posisi mereka diberikan pada mereka hak istimewa untuk menjadi tuli terhadap ide-ide yang proses kebebasan berbicara telah dibawa ke perhatian publik.

\section{Etika Foto Jurnalistik}

Merriam-Webster (Bersak, 2006: 5) mendefinisikan etika sebagai kode etik yang baik bagi seorang individu atau kelompok, atau sesuatu yang berkaitan dengan moralitas, moral, prinsip, dan standar. Etika dalam foto jurnalistik secara internasional diatur dalam the National Press Photographers Association's Code of Ethics, di mana memberi petunjuk apa saja yang boleh dilakukan dan yang tidak boleh dilakuan. Ada 9 aturan yang menjadi dasar pengambilan gambar dalam foto jurnalistik, yakni:

1. Foto harus akurat dan komprehensif dalam representasi subyek. Menolak untuk memanipulasi oleh peluang foto yang diciptakan.

2. Foto harus lengkap dan memotret atau merekam subyek sesuai dengan konteks.

3. Hindari stereotip individu dan kelompok. Mengenali dan bekerja untuk menghindari efek bias dari pemaknaan oleh diri sendiri ketika bekerja.

4. Perlakukan semua subjek dengan hormat dan bermartabat. Memberikan pertimbangan khusus untuk subjek yang menjadi korban kejahatan atau tragedi.

5. Ketika memotret subjek tidak sengaja berkontribusi, mengubah, atau berusaha untuk mengubah atau memengaruhi peristiwa.

6. Editing harus menjaga integritas konten gambar fotografi dan konteks. Jangan memanipulasi gambar atau menambah atau mengubah suara dengan cara apapun yang dapat menyesatkan pemirsa atau ketidaksesuaian subjek.

7. Jangan membayar narasumber atau subjek atau memberikan hadiah material atas informasi atau partisipasinya.

8. Jangan menerima hadiah, bantuan, atau kompensasi dari mereka yang mungkin berusaha memberikan pengaruh.

9. Jangan sengaja menyabotase upaya wartawan lainnya

(Newseum Photo Ethics 2014: 6)

Fotografi dan video yang dapat mengungkapkan kebenaran, mengekspose kesalahan dan kelalaian, menginspirasi harapan dan pemahaman dan menghubungkan orang di seluruh dunia melalui bahasa dari pemahaman visual. Foto-foto juga dapat menyebabkan kerusakan besar jika mereka tanpa perasaan mengganggu atau dimanipulasi. Oleh karena itu, foto jurnalistik adalah 'teknologi diri' sebuah alat untuk menggali masyarakat dan budaya untuk mencapai kebenaran tentang 'sejarah masa kini'. Apa yang ditampilkan dalam foto jurnalistik mewakili cerita keseluruhan dari berita. Foto yang ada di headline media cetak merupakan merepresentasi dari kejadian secara keseluruhan. 
Gambar 1

Foto Headline Suara Merdeka Edisi 11

Oktober 2015

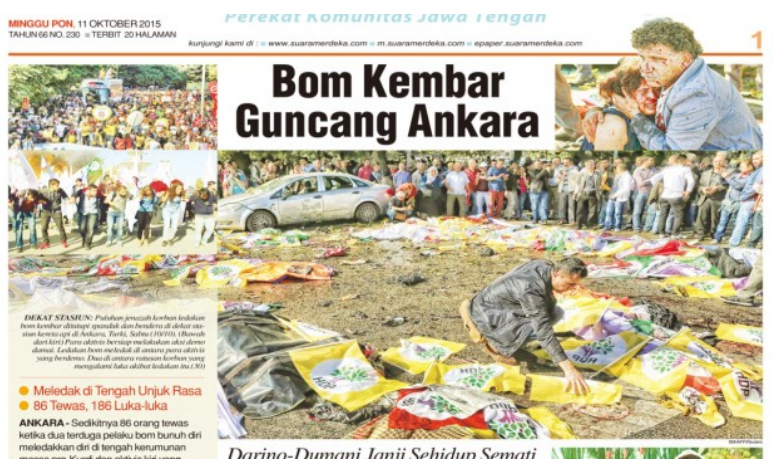

Sumber: olah data pribadi

Suara Merdeka edisi 11 Oktober 2015 halaman utama menyajikan pemberitaan teror bom yang terjadi di Ankara, Turki. Sajian tersebut dari kajian utilitarian media massa menampilkan foto-foto detail peristiwa berdasarkan azas manfaat. Dari aspek agenda setting media sajian tersebut memberikan kesadaran (awareness) betapa mengerikan akibat dari serangan teror berupa ledakan bom di dekat stasiun kereta api. Ledakan bom bunuh diri yang menyebabkan 86 korban meninggal dunia tersebut dikutuk sebagai tindakan tidak beradab. Media memberikan pesan bahwa bom bunuh diri meninggalkan duka mendalam bagi keluarga korban. Tindakan teror tidak hanyamenimbulkan korban materi, tetapi juga jiwa bagi orangorang yang belum tentu bersalah.

Etika adalah subjektif. Professor Kenneth Kobré dalam bukunya Photojournalism, the Professionals' Approach (Bersak, 2006: 7) menuliskan bahwa foto jurnalistik tidak memiliki kitab suci, tidak ada tokoh agama yang mengoreksinya. Tidak ada garis tegas boleh atau tidak untuk memotret objek. Foto jurnalistik berpedoman pada masalah apa yang disebut "kebenaran fotografi, yaitu apakah gambar tertentu akurat mewakili subjek atau apakah itu menyesatkan masyarakat. Oleh karena itu dilema etis muncul antara etika jurnalistik dan profesionalisme. Etika foto jurnalistik dapat dipandang dari beberapa perspektif, di antaranya:

\section{Perspektif The Categorical Imperative Ethics}

Perspektif The Categorical Imperative Ethics merupakan teori absolut yang menyatakan bahwa sesuatu yang benar adalah benar, dan yang salah adalah salah. Pemikiran Immanuel Kant ini mengharuskan apa yang diterima seseorang harus diterima untuk semua orang seperti teori "nondiscrimination clause" (Bersak, 2006: 9). Ketika Headline Suara Merdeka menampilkan gambar korban teror bom di Turki bertentangan dengan moral seorang jurnalis yang menampilkan korban dengan suasana berdarah-darah. Hal ini tidak sejalan dengan perspektif The Categorical Imperative Ethics atau seringkali disebut dengan etika deontologi.

Perspektif deontologi memandang bahwa suatu perbuatan dilakukan bukan atas dasar tujuan seharusnya, perbuatan dilakukan atas dasar kewajiban dan legalistas. Artinya seharusnya media melakukan "kewajiban" berdasarkan "kewajiban" itu sendiri, bukan berdasarkan tujuan. Sehingga tidak perlu alasan lain untuk melakukan sebuah perbuatan yang hingga akhirnya bisa dilakukan. Sesuai dengan perspektif tersebut, media memiliki idealisme dalam menampilkan foto-foto tentang peristiwa. Media perlu memperhatikan aspek-aspek psikologis audiens ketika hendak menampilkan gambar-gambar yang disajikan.

Deontologi jurnalisme membantu dalam mempertajam makna tanggung 
jawab. Moral deontologi merupakan keseluruhan aturan dan moral yang berlaku dan diterima oleh suatu masyarakat tertentu sebagai arah atau pegangan dalam bertindak dan dirumuskan dalam kerangka baik/buruk. Ada tiga prinsip utama deontologi jurnalisme (B. Libois, 1994: 6-7 dalam Haryatmoko, 2007: 45) yaitu:

1. Hormat dan perlindungan atas hak warga negara akan informasi dan sarana-sarana yang perlu untuk mendapatkannya. Di dalamnya mengandung unsur perlindungan atas sumber berita, pemberitaan yang benar dan tepat, jujur, dan lengkap; pembedaan antara fakta dan komentar, informasi dan opini.

2. Hormat dan perlindungan atas hak individual lain dari warga negara; hak atas kesehatan fisik dan mental; hak konsumen dan hak untuk berekspresi dalam media; serta hak jawab; hak akan privacy; praduga tak bersalah, hak akan reputasi, hak akan citra yang baik, hak bersuara, dan hak akan rahasia komunikasi.

3. Ajakan untuk menjaga harmoni masyarakat, melarang semua bentuk provokasi atau dorongan yang akan membangkitkan kebencian atau ajakan pada pembangkangan sipil.

\section{Perspektif The Principle of Utility}

Etika Utilitarianisme seringkali struktur pemaknaan menekankan pada prinsip ekonomi karena berdasarkan pada asas manfaat. Konsep "the greatest good for society" ini mengacu pada tindakan moral yang dibenarkan sepanjang memberi manfaat untuk masyarakat. Foto jurnalistik boleh disampaikan secara rinci karena untuk pengetahuan masyarakat secara jelas. Hal ini bisa menjadi tidak peka terhadap tuntutan etis dalam masalah prosedur atau pilihan sarana termasuk di dalamnya adalah yang berkaitan dengan foto jurnalistik yang ditampilkan.

\section{Perspektif The Golden Mean}

Perspektif The Golden Mean mengutamakan pengendalian diri (moderation) dan keseimbangan (balanced). Apa yang ditampilkan media itu haruslah menarik tapi tidak boleh rinci.

\section{Perspektif The Veil of Ignorance}

Perspektif The Veil Ignorance menjelaskan bahwa fotografer atau editor menempatkan dirinya sebagai subjek. Bagaimana nurani berperan, apakah merasakan hal baik ketika menjadi subjek. Jika yang dirasakan tidak baik maka sebaiknya mengambil gambar dari sudut pandang yang lain.

Nurani media menjadi dasar pertimbangan sebelum menurunkan foto-foto yang menonjolkan kengerian. Detail gambar korban bom yang berserakan kemudian ditutupi kain menimbulkan dampak psikologis kepada khalayak. Pembaca bisa kehilangan selera ketika di pagi hari ketika mengambil koran yang pertama kali terlihat adalah gambar kengerian.

Gambar pasangan insan yang berangkulan dengan wajah berdarah-darah menambah kengerian di benak pembaca. Maka, nurani sebagai landasan etika memegang peranan penting sebelum mengambil keputusan apakah gambar tersebut penting diturunkan atau tidak dibandingkan dengan alternatif foto-foto. Selagi terdapat pilihan foto lain yang lebih soft atau tidak terdapat gambar berdarah-darah, foto tersebut bisa menjadi alternatif. 


\section{Perkembangan Etika Foto Jurnalistik}

Foto di media cetak memberikan cerita mengenai berita itu sendiri. Di abad 20, foto seringkali mendominasi halaman depan surat kabar (Kobre, 347 dalam Bersak, 2006: 16). Salah satu perbedaan antara awal abad kedua puluh dan modernitas adalah bahwa pembaca hari ini menuntut dari foto-foto berita dalam hal integritas dan etika. Misalnya adalah ketika foto mengenai perang. Ada dilema etis antara fotografer dengan subjek yang dipotretnya, entah mau menolong subjek atau tetap menjalankan profesinya untuk memotret kejadian secara profesional.

Teknologi dunia fotografi terus berkembang pada tahun 1980-an dan 1990-an, termasuk etika foto jurnalistik.. Awal 1990-an melihat berita fotografi murni digital. Di tahun 1980, majalah dan surat kabar mulai bereksperimen dengan menggabungkan gambar digital ke dalam layout mereka. Teknologi digital dalam foto bisa menjadi manipulasi karena ada upaya untuk meningkatkan tampilan dan komposisi gambar,

Tidak ada batasan jelas untuk mengatakan suatu foto jurnalistik melanggar etika atau tidak, baik atau buruk, bertanggung jawab atau tidak bertanggung jawab secara keseluruhan. Manipulasi foto dibenarkan atau tidak, tergantung dari perspektif etika yang digunakan. Paling tidak, di Indonesia memiliki pedoman Kode Etik Jurnalistik sebagai pedoman dasar fotografer dalam menjalankan profesinya. Pedoman dalam kode etik tersebut menjadi landasan pewarta foto dalam mengabadikan sebuah peristiwa. Pewarta foto bisa mengambil gambar dari berbagai sudut pandang, namun harus memperhatikan aspek-aspek kejujuran, kebenaran, dan obyektifitas.

Perkembangan teknologi informasi menyebabkan jurnalisme dapat dimiliki semua orang. Saat ini semua orang memiliki smartphone yang di dalamnya ada fitur kamera sehingga siapapun bisa mengambil foto mengenai peristiwa yang dianggap memiliki nilai berita. Ada kekhawatiran mengenai persoalan etika dalam jurnalisme warga. Ke depan, fenomena jurnalisme warga menjadi tantangan yang dihadapi media karena tidak terikat oleh profesionalisme dan kode etik, yang bisa membahayakan integritas gambar/foto tanpa disadarinya. Media harus berhati-hati dalam penggunaan foto yang berasal dari jurnalisme warga.

\section{PENUTUP}

\section{Simpulan}

Memahami etika foto jurnalistik diperlukan dalam setiap sajian di media cetak. Melalui foto jurnalistik yang ditampilkan di media cetak, khalayak mempersepsikan dalam berbagai makna. Harian Suara Merdeka dalam menampilkan foto utama dalam edisi 11 Oktober 2015 dalam kejadian bom di Ankara menimbulkan berbagai makna dalam etika foto jurnalistik. Foto jurnalistik berfungsi sebagai media sosialisasi, kritis, dan edukasi. Dalam fungsi-fungsi tersebut, etika menjadi panduan layak atau tidak layak foto diturunkan. Untuk memandang foto jurnalistik terdapat empat perspektif etis dalam memahami pesan-pesan yang disampaikan.

Setelah memahami pesan-pesan dalam berbagai perspektif tersebut, khalayak dapat memandang dalam perspektif mana etika sebuah foto yang ditayangkan media. Menjalankan makna kekritisan adalah bentuk fungsi media sebagai bentuk pengawasan. Sajian foto Suara Merdeka dalam bom Ankara mengedepankan deskripsi dampak hebat dari aksi terorisme. Banyaknya korban jiwa menimbulkan persepsi bahwa serangan bom bunuh diri tersebut tindakan yang tidak berperikemanusiaan. 
Pesan yang disampaikan adalah pelaku bom bunuh diri sangat keji dan tidak beradab karena akibat perbuatannya menimbulkan hilangnya nyawa 86 orang yang belum tentu bersalah. Dalam kajian utilitarian, Suara Merdeka menurunkan foto tersebut berdasarkan aspek manfaat. Foto jurnalistik diturunkan dalam deskripsi detal untuk memperjelas situasi yang terjadi di tempat peristiwa. Pengetahuan masyarakat terhadap persitiwa itu menjadi semakin jelas karena dampak yang ditimbulkan akibat bom Ankara sangat detail. Pada sisi lain, tuntutan etis dalam masalah prosedur atau pilihan sarana termasuk di dalamnya adalah yang berkaitan dengan foto jurnalistik yang ditampilkan.

Dalam kajian deontologis, media memiliki nilai-nilai idealisme yang dijunjung tinggi dalam menggambarkan sebuah kejadian. Media perlu memperhatikan aspekaspek psikologis audiens sebelum menurunkan teks dan gambar. Deontologis memaknai tanggung jawab moral dari seluruh aturan yang berlaku di masyarakat.

\section{Saran}

Keberadaaan foto jurnalistik menimbulkan dampak luar biasa bagi khalayak. Foto merupakan bentuk komunikasi yang efektif, tanpa harus menjelaskan secara detail melalui teks-teks, gambar telah berbicara secara jelas. Foto mampu membuat imajinasi khalayak penikmat foto serta mencerminkan kejujuran sepanjang foto jurnalistik melalui proses yang memenuhi kaidah yang diatur dalam UU No 40 Tahun 1999 tentang Pers serta Kode Etik Jurnalistik.

Kaidah-kaidah dalam UU Pers dan Kode Etik Jurnalistik menjadi panduan penting sebelum pengelola media mengambil kebijakan untuk menurunkan foto jurnalistik. Dampak yang ditimbulkan dari penayangan foto jurnalistik bisa mengganggu psikologis khalayak. Di sisi lain, media memilik peran untuk menjelaskan secara detail sebuah peristiwa sehingga pesan kekejaman sebuah aksi teror mudah dicerna oleh masyarakat pembaca.

Melalui foto jurnalistik yang memperhatikan UU Pers dan Kode Etik Jurnalistik, pembaca diharapkan bisa mengambil nilai-nilai atas pesan yang disampaikan. Memahami etika foto jurnalistik bukan hanya menjadi ranah media, namun khalayak memiliki kompetensi luas. Hal ini dimaksudkan supaya pesan atas foto tersampaikan dengan baik sekaligus nurani media atas penayangan foto jurnalistik tidak mengganggu batas-batas psikologis khalayak.

\section{DAFTAR PUSTAKA}

Alwi, Audy Mirza. (2004). Foto Jurnalistik: Metode Memotret dan Mengirim Foto ke Media Massa. Jakarta: Bumi Aksara.

Baran, Stanley J and Davis, Dennis K. (2012). Mass Communication Theory: Foundations, Ferment, and Future Sixth Edition. USA: Wadsworth.

Bersak, Daniel R. (2006). Ethics in Photojournalism: Past, Present and Future. USA: Massachusetts Institute of Technology.

Bresson, Henri Cartier.(1952). The Decisive Moment Photography. New York: Drager. . Jurnalisme Positif: Panduan Kerja Para Jurnalis Berita Satu Media Holding.

Haryatmoko. (2007). Etika Komunikasi. Yogyakarta: Penerbit Kanisius.

Newseum Photo Ethics. (2014) dalam http://www.newseum.org/wpcontent/uploads/2014/08/education_LC O_photoethicsLP.pdf diakses pada hari Kamis, 3 Desember 2015 jam 13.20 WIB. 
McQuail, Dennis. (2011). Teori Komunikasi Massa. Jakarta: Salemba Humanika

Soesiswo, Mas, Amir Machmud NS, dan Adi Ekopriyono. (2003). Jurnalisme Pukulan Dua Inci. Semarang: Yayasan Karyawan Suara Merdeka

UU No 40 Tahun 1999 tentang Pers dan Kode Etik Jurnalistik.

Wilkins, Lee and Clifford G. Christians. (2009). The Handbook of Mass Media Ethics. New York and London: Routledge.

Wibowo, Indiwan Seto. (2004). Introduction to Journalism dalam https://www.academia.edu/6499156/intr oduction to journalism diakses pada hari Jumat tanggal 4 Desember 2015 jam 13.13. WIB 